\title{
IDENTIFICATION OF THE POTENTIAL RISK AREAS REGARDING THE FLOODS OCCURRENCE WITHIN SMALL MOUNTAIN CATCHMENTS
}

DOI: http://dx.doi.org/10.18509/GBP.2016.24

UDC: 556.166.048:528.93(498)

\author{
PhD Student Oana-Elena Hapciuc \\ PhD Student Marina Iosub \\ PhD Student Anamaria Ioana Tomașciuc \\ Lecturer PhD. Ionuț Minea \\ Prof. PhD. Gheorghe Romanescu
}

Alexandru Ioan Cuza University of Iași, Faculty of Geography and Geology, Department of Geography, Iasi, Romania

\begin{abstract}
Identifying the potential risk areas concerning the floods occurrence represent a sustainable approach to the rational management of emergencies within the small mountain catchments. The analysis focuses on the study of morphometric parameters and the land-use that play an important role in the occurrence of hydrological risk phenomena and check the formation of surface runoff. In this context, the work aims to identify the major flooding-prone areas by calculating the Flood Potential Index (FPI). The proportions of each analyzed factor were integrated within this index and they were obtained by applying the Analytical Hierarchy Process (AHP). This methodology was applied to the Suceviţa River catchment, located in the northern part of the Eastern Carpathians (Romania). In the last decade, Suceviţa's catchment has been affected by extreme hydrological events (in 2010, it was recorded a $467 \mathrm{~m}^{3} / \mathrm{s}$ flow, value that exceeds the probability of $0.1 \%$ ) that caused extensive damage by flooding large areas of land. The analysis points out that the potential risk areas concerning the floods occurrence correspond to the surface of the studied catchment in proportion of $6,43 \%\left(13 \mathrm{~km}^{2}\right)$. The result provides working material for the local decision-makers or a tool in promoting some land-use policies in order to reduce the flood risk.
\end{abstract}

Keywords: flooding, risk, GIS, Sucevița catchment, analysis

\section{INTRODUCTION}

The frequency and the consequences of the extreme floods have recently increased worldwide in view ofthe climate change, the population growth and the uncontrolled territorial development [1].

The analysis of the triggering parameters and the application of certain methodologies to quantify the flooding risk ofthe affected areas can provide to the concerned authorities useful information in order to determine the right measures to reduce flood damages.

The Flash-Flood Potential Index (FFPI) has been proposed by Smith, 2006 [2] taking into account certain physico-geographical factors which were favourable in identifying the areas with a high flash-flood potential within the Colorado catchment.

This geographical indicator was adapted for Romania and it was applied on the catchments considering some physico-geographical factors such as: land cover and land- 
use, hydro-physical characteristics of the soils (texture), lithology, slopes, rainfall, etc. [3-5].

To identify the major flooding-prone areas, the weights of influence of the analyzed factors were integrated into the flash-flood potential index, and they were obtained by applying the Analytical Hierarchy Process method (AHP). This approachis often used and applied in a wide range of scientific fields (social, economic, environmental sciences, etc.) and it helps understanding an issue using a hierarchical framework [6].

The present paper deals with the current issue concerning the emergency situation management caused by floods and it suggests methods for identifying the flood-prone areas using the geographical information systems. The character of this study is practical because it supports the implementation of the objectives of the Directive 2007/60/EC in Romania, by proposing some models that could be included in the General Urban Plans (GUP) or used as tools in planning and establishing measures for flood risk mitigation.

\section{STUDY AREA}

The Suceviţa catchment is located at the contact area of the Obcina Mare with the Rădăuți Depression, in the north-eastern part of Romania (Fig. 1). The Suceviţa river springs from the Obcina Mare, between Suceviţa and Poiana Micului localities, from the altitude of $1100 \mathrm{~m}$ and after a $41 \mathrm{~km}$ course, it flows down into the Suceava river [7].

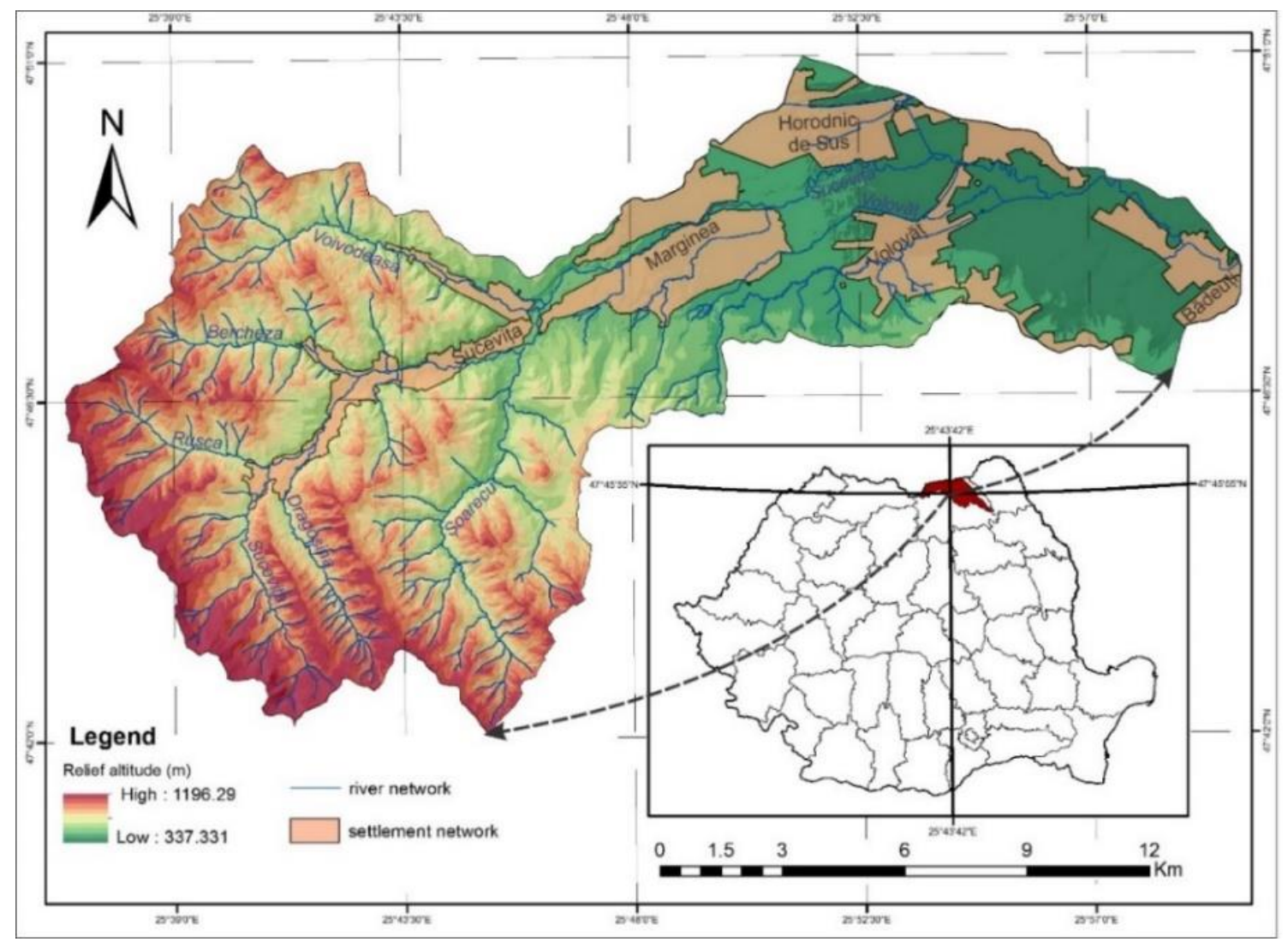

Figure 1. Geographical location of the study area

In terms of administration, the Suceviţa catchment is located within the Suceava county and it is considered a complex area, mostly rural. The spatial distribution of the localities in the studied area is conditioned by the natural setting which helps them develop: slope 
relief, exposure and orientation of slopes, soils, large area covered with forests (58\% of the total area of the catchment in 2012) and hydrography.

Most of the localities of the Suceviţa catchment have expanded in the areas adjacent to the river. Due to this expansion over the years, these localities have suffered extreme hydrological events in which there have been significant damages. However, this situation hasn't limited the expansion of the built-up area to the high flood-prone zones, so that, in recent years, it was necessary to implement some flood protection policies.

\section{MATERIALS AND METHODS}

The assessment of the potential flood areas can be performed considering the main factors in triggering flooding in the small catchments.

The methodology of the flash-flood potential index has been applied to the Suceviţa catchment based on the weights of influence of the analyzed factors, obtained by applying the analytical hierarchy process in order to identify and analyze the areas highly exposed to flood events.

The data processing and the calculation of the final result was performed using ArcGis, the spatial analysis software (ESRI, Redlands, CA, USA). The morphometric indices such as the slope and the profile curvature were derived from the Numeric Model of the Terrain 1:5000 into the raster format (performed after vectoring the level curves on the topographic plans) with a pixel size of $10 \times 10 \mathrm{~m}$. The geological and the soil maps were obtained by polygon vectoring of the geological and pedological maps 1:200,000 (Rădăuți sheet). The land-use was extracted from Corine Land Cover 2012.

The applied methodology includes the main physico-geographical factors that may influence the flood occurrence: slope, plan curvature, soil texture, land-use and lithology (Fig. 2). After carrying out the necessary thematic layers, evaluation rates were granted from 1 to 5 where, 1 corresponds to the characteristics that bring a minimum contribution to the flood occurrence, and 5 is the maximum value (Table 1).

In order to determine the relative weights, information gathered from the specialty literature and from the questionnaires applied to the local authorities of the studied catchment were used.

The slope of the land was taken into account in order to identify the perimeters that have a significant flooding potential. The values of the slopes follow the distribution of the altitudinal steps, being higher in the western half and lower on the east side, revealing the contact area between the Obcina Mare and the Rădăuți Depression. Evaluation rates were given to these classes according to the impact they have on flooding occurrence. Thus, the low slopes gradient $\left(<5^{0}\right)$ were placed into the 5 class, while those with a slope greater than $30^{\circ}$ into the first class.

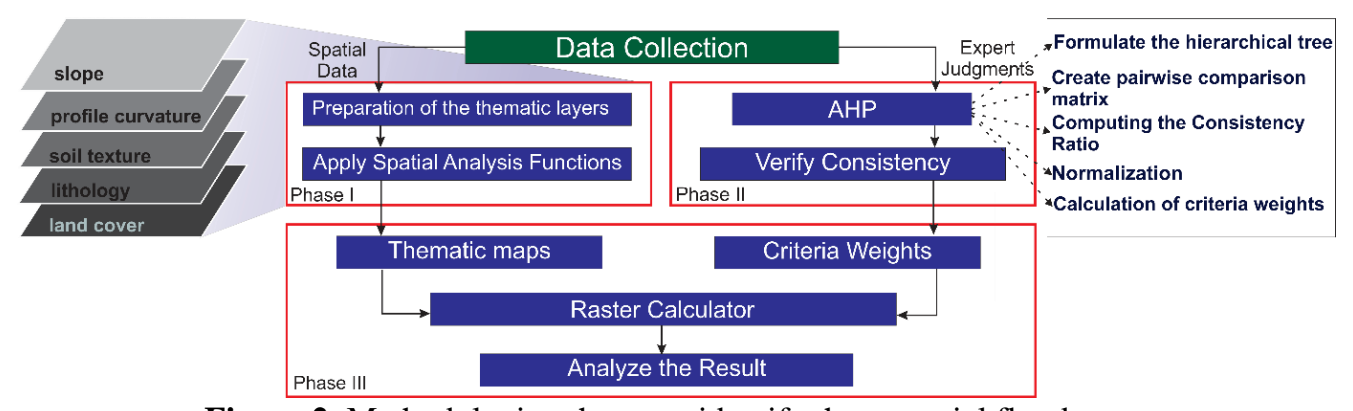

Figure 2. Methodologic scheme to identify the potential flood areas 
Table 1. Classification and Indexing of the physico-geographical factors used in the assessmentof the

\begin{tabular}{|c|c|c|c|c|c|}
\hline $\begin{array}{l}\text { Slope } \\
\left({ }^{\circ}\right)\end{array}$ & $\begin{array}{c}\text { Profile } \\
\text { curvature } \\
\text { (radians } / \mathbf{m})\end{array}$ & Soil texture & Land-use & $\begin{array}{l}\text { Lithology } \\
\text { (hardness) }\end{array}$ & $\begin{array}{l}\text { Evaluation } \\
\text { rate }\end{array}$ \\
\hline$>30$ & - & $\begin{array}{l}\text { sandy-clayey / } \\
\text { clayey-sandy, } \\
\text { sandy / sandy- } \\
\text { clayey, } \\
\text { clayey-sandy }\end{array}$ & $\begin{array}{l}\text { mixed forests, } \\
\text { coniferous } \\
\text { forests, deciduous } \\
\text { forests }\end{array}$ & $\begin{array}{l}\text { Gravels and sands, } \\
\text { gravel terraces, sands- } \\
\text { diluvial proluvial } \\
\text { deposits }\end{array}$ & 1 \\
\hline $20-30$ & - & $\begin{array}{l}\text { sandy-clayey / } \\
\text { clayey } \\
\text { clayey-sandy / } \\
\text { clayey, } \\
\text { clayey, } \\
\text { varied texture }\end{array}$ & $\begin{array}{c}\text { shrubs transition } \\
\text { areas }\end{array}$ & $\begin{array}{c}\text { Grey loamy marls, } \\
\text { gypsum and salt, loamy } \\
\text { marls with sand } \\
\text { intercalations, } \\
\text { Sandstones, marlsand } \\
\text { loams }\end{array}$ & 2 \\
\hline $10-20$ & $0,9-8,33$ & $\begin{array}{l}\text { clayey-sandy / } \\
\text { clayey loamy } \\
\text { clayey / clayey } \\
\text { loamy }\end{array}$ & $\begin{array}{l}\text { complex crops } \\
\text { areas, unirrigated } \\
\text { arable land }\end{array}$ & $\begin{array}{l}\text { Sandstone flysch with } \\
\text { shaly intercalations, } \\
\text { conglomerates with } \\
\text { green schists elements }\end{array}$ & 3 \\
\hline $5-10$ & $0-0,9$ & $\begin{array}{l}\text { clayey loamy } \\
\text { clayey loamy / } \\
\text { loamy }\end{array}$ & $\begin{array}{l}\text { secondary } \\
\text { grasslands }\end{array}$ & $\begin{array}{c}\text { Chalky flyschwith } \\
\text { sandstone intercalations }\end{array}$ & 4 \\
\hline$<5$ & $-7,55-0$ & - & $\begin{array}{l}\text { watercourses, } \\
\text { rural area, } \\
\text { industrial units }\end{array}$ & $\begin{array}{c}\text { Sandstone flysch } \\
\text { (Tarcău) with shaly } \\
\text { intercalations), striped } \\
\text { schistic flysch }\end{array}$ & 5 \\
\hline
\end{tabular}

The map relating to the profile curvature identifies the convex surfaces, showing an accelerated runoff of water (represented on the map by negative values), the concave surfaces presenting a decelerated runoff (positive values) and the horizontal surfaces [8]. The thematic layer was regrouped into three classes: a class with negative values (-7.55 $0)$ represented by convex surfaces at a rate of $50.59 \%$, the second class $(0-0.9)$ representing the flat surfaces and the concave surfaces class $(0.9-8.33)$ with a percentage of $47.43 \%$.

The land-usehas been extracted from Corine Land Cover database of 2012 (European Environmental Agency) in vector format. The evaluation rates were given after rasterization depending on the impact of each class on the flood occurrence events [9]. Thus, the areas dominated by forests ( $58 \%$ of the Suceviţa catchment surface) received the evaluation rate of 1 , while the built-up space $(11.12 \%)$, the watercourses $(0.56 \%)$ and the industrial or commercial units $(0.13 \%)$ received the maximum evaluation rate.

The soil texture represents a determining factor in the runoff process and the flood occurrence. Thus, the hydrological soil groups have been developed in the USDA (United States of Agriculture, Natural Resources Conservation Service) and it resulted that the proportion of clay, dust and sand, namely the soil texture, best defines their drainage capacity [10]. Regarding the Suceviţa catchment, the predominant hydrological soil groups are the A and B ones, with a percentage of $40.51 \%$ and $48.58 \%$. The soils of the $\mathrm{A}$ and $\mathrm{B}$ groups have a rough texture and also a low runoff potential. These type of soils gives a good drainage of the surface water towards the bottom of the soil profile, especially during significant precipitations [10].

In terms of lithology, the Suceviţa catchment is located at the contact area of the External Flyschwith the Moldavian Platform and, in tectonic terms, two nappes overlap the studied 
region: the eastern limit of the Tarcău Nappe and the Vrancea Nappe up to the contact with the Moldavian Platform. The lithology is represented by the external flysch which is characterized by sandstones, sandy limestones, compacted marls and clays, and solid rocks superior to those that form the platform deposits (loamy marlswith sand intercalations, gravels).

\section{RESULTS AND DISCUSSION}

To identify the flooded-prone areas of the Suceviţa catchment, the analysis was based on the study of the physico-geographical parameters (the morphometric ones and the landuse) which played an important role in the distribution of the hydrological risk events. The methodologies $[2 ; 11]$ have been adapted to identify areas of concern and to integrate the results in order to achievethe flood management in the smallcatchments.

Based on the values set by Saaty, 1980 [11], the criteria are converted into numerical values by simple comparisons related to previous studies, questionnaires applied to decision-makers and personal opinions on the analyzed issue. The calculation matrix is essential for obtaining the relative weight of each analyzed factor.

These weights can be automatically calculated by using some specialized software products (Expert Choice, IDRISI) or Microsoft Excel, and they are considered tools called Multi-Criteria Decision Analysis (MCDA) [12]. In the case of the present study, it was performed a calculation software in Microsoft Excel in order to determine the weights based on pairs.

The weights obtained by applying the analytical hierarchy process (AHP) have been integrated into ArcGis to prepare the flood risk map.

The formula used in the analysis is the following:

FPI $=3.88 *$ slope $+2.61 *$ profile curvature $+1.03 *$ texture $+1.75 *$ land use + $0.73 *$ lithology.

Thus, in order to prepare the map of the flood risk distribution areas, the above-mentioned methodology was applied. The obtained values rangedbetween 12.2 to 44.1 and they were grouped into five classes using the Natural Breaks classification of the ArcGis (table 2).

Table 2. The classes of values for the flash-flood potential index

\begin{tabular}{l|c|c|c|c|c} 
Evaluation rate & 1 (very low) & 2 (low) & 3 (medium) & 4 (high) & 5 (very high) \\
\hline Classes & $12,2-19,7$ & $19,7-24,2$ & $24,2-30,7$ & $30,7-37,8$ & $37,8-44,1$
\end{tabular}

The areas with high slope values $\left(>30^{\circ}\right)$, those covered by forests or those that allow a high infiltration of water having the appropriate soil texture and lithological substratum are included within the first two classes. These areas are distributed both in the western part of the studied catchment, with $90 \%$ corresponding to the Obcina Mare, and also in the downstream of the Sucevița river (Fig. 3). 


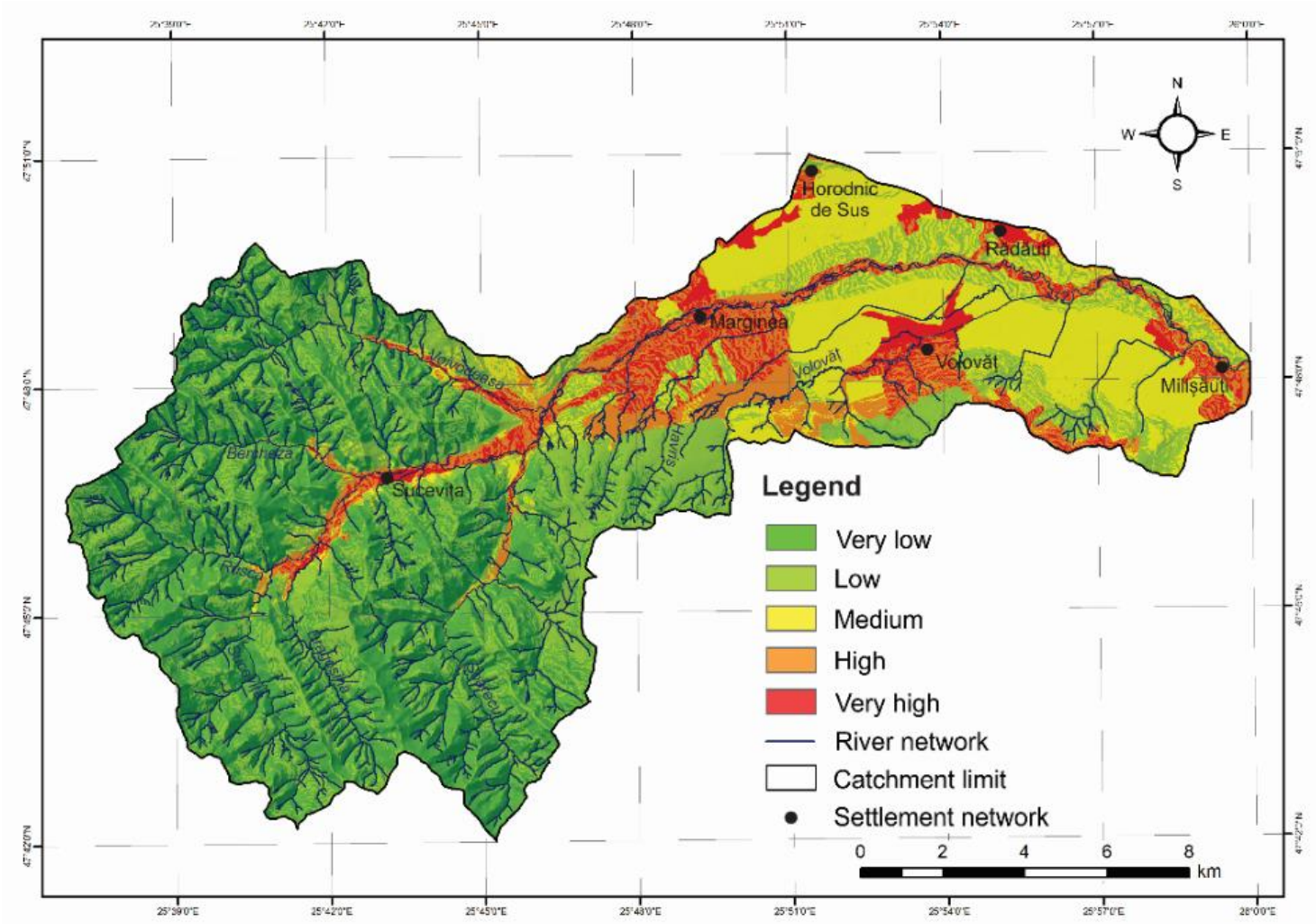

Figure 3. Distribution of the flood risk areas in the Suceviţa catchment

The very high values of the index fall within 37.8 and 44.1 and correspond to the major flood risk class. These values represent $6.43 \%\left(13 \mathrm{~km}^{2}\right)$ of the Suceviţa catchment and they are particularly present in the flood-prone areas. These areas are distributed along the main watercourse of Suceviţa. They are characterized by slope values lower than $5^{\circ}$, with a high water resistance due to the built-up space. Thus, the settlements located alongside the Suceviţa river and its right tributary, Volovăţ, face a major risk of flooding.

\section{CONCLUSIONS}

The vulnerability of this area is determined by the spatial distribution of the settlements in the floodplain or in the water drainage zones, and the recent years' floods were notable for producing significant damage, revealing the weak capacity of the authorities to absorb the effects of the phenomenon and to recover after it.

The analysis of the maps highlights that the areas with high index values are distributed along the main watercourse of the Sucevita river and they represent $6.43 \%$ of the catchment, and the very low values correspond to the western part areas, in the Obcina Mare zone, with a percentage of $36.87 \%$.

The result can be used as a guidelineforthe local councils and other interested parties in order to prepare the population located in the flood risk areas, and to establish appropriate measures to mitigate the damage or to promote a land-use policy of the flood-prone zones. 


\section{REFERENCES}

[1] Romanescu Gh., Stoleriu C., Morpho-bathymetry and gis-processed mapping in delimiting lacustrine wetlands: the Red Lake (Romania), International Scientific Conference Geobalcanica, Republic of Macedonia, 2015, pp 85 - 96.

[2] Smith, G., Flash flood potential: determining the hydrologic response offfmp basins to havy rain by analyzing their physiographic characteristics, 2003 http://www.cbrfc.noaa.gov/papers/ffp_wpap.pdf

[3] Mătreață S., Mătreață M., Metodologie de estimare a potențialului de producere a viiturilor rapide în bazine hidrografice mici, Comunicări de Geografie, Vol. XIV, Editura Universității din București, România, 2010, pp 197 - 204.

[4] Minea G., Assessment of the Flash Flood Potential Index of Bâsca River Catchment (Romania) Based on Physiographic Factors, Central European Journal of Geosciences, 2013, 5(3), pp 344 - 353.

[5] Tîrnovan A., Cojoc G.M., Romanescu Gh., Obreja F., Predicting the potential index of major floods production in the Suha basin (Suha Bucovineană), $2^{\text {th }}$ International Conference - Water resources and wetlands. 11 - 13 Septembrie, Tulcea, 2014, pp 539 545.

[6] Stefanidis S., Stathis D., Assessment of flood hazard based on natural and anthropogenic factors using analytic hierarchy process (AHP), Nat. Hazards, 68, 2013, pp $569-585$.

[7] Hapciuc O.E., Minea I., Romanescu Gh., Tomașciuc A.I., Flash flood risk management for small basins in mountain-plateau transition zone. Case study for Sucevița catchment (Romania), International Multidisciplinary Scientific GeoConference - SGEM, Bulgaria, 2015, pp 301 - 308.

[8] Constantinescu Ș., Observații asupra indicatorilor morfometrici determinați pe baza MNAT, Bucuresti, România, 2006, [http://earth.unibuc.ro/articole/observaii-asupraindicatorilor-morfometrici-determinai-pe-bazamnat] consulted on: 13.XI.2011.

[9] Zaharia L., Costache R., Prăvălie R., Minea G., Assessment and mapping of flood potential in the Slănic catchment in Romania, J. Earth Syst. Sci., 2015, 124(6), pp 1311 $-1324$.

[10] Chendeș V., Resursele de apă din Subcarpații de la Curbură. Evaluări geospațiale, Editura Academiei Române, București, 2011.

[11] Saaty T.L., The Analytic Hierarcy Process, McGraw-Hill: New York, NY, 1980, USA.

[12] Siddayao G., Valdez S., Fernandez P., Analytic hierarchy process (AHP) in Spatial Modeling for Floodplain Risk Assessment, International Journal of Machine Learning and Computing, 2014, vol 4, no. 5, pp $450-457$ 